\title{
Performance evaluation of fly ash-based geopolymer concrete incorporating nano slag
}

\author{
Ali I.M. ${ }^{1{ }^{*}}$, Naje A.S. ${ }^{2}$, Al-Zubaidi H.A.M. ${ }^{3}$ and Al-Kateeb R.T. ${ }^{2}$ \\ ${ }^{1}$ Karbala Technical Institute, Al-Furat Al-Awsat Technical University, 56001 Karbala, Iraq \\ ${ }^{2}$ College of Engineering, Almuthana University, Iraq \\ ${ }^{3}$ Department of Environmental Engineering, College of Engineering, University of Babylon, Babylon, Iraq \\ Received: 12/10/2018, Accepted: 13/12/2018, Available online: 07/01/2019 \\ *to whom all correspondence should be addressed: e-mail: ali_isam@ymail.com \\ https://doi.org/10.30955/gni.002917
}

\section{Abstract}

This study investigates the effectiveness of fly ash-based geopolymer concrete, which can be used as an alternative material to replace the normal concrete. The concrete mixture was prepared by mixing fly ash, fine aggregate, nano-slag, and Super Plasticizer (SP) in $\mathrm{Na}_{2} \mathrm{SiO}_{3} / \mathrm{NaOH}$ solution. The mixture was divided into three different groups, with constant water to fly ash ratio of 0.1 , and different alkaline content: $0.4,0.45$, and 0.5 of fly ash rather than two curing techniques (moist and autoclave). Several hardeness properties of concrete like compressive strength, density; and splitting tensile strength were examined after $28 \mathrm{~d}$. The microstructural development of geopolymer concrete was monitored using X-Ray Diffractometer. Based on the results of this investigation, it is recommended to cure the geopolymer concrete by autoclaving rather than the traditional moist technique, especially at lower alkaline dosage. However, the partial addition of nano slag by weight of FA had a positive effect on both curing techniques.

Keywords: Fly ash, geopolymer concrete, strength, nano slag, curing, XRD, alkaline.

\section{Introduction}

Geopolymer is a class of inorganic polymers formed by reacting silica-rich and alumina-rich solids with a high alkaline solution, which combines the properties of polymers, ceramics and cements. To fulfill the commitment of sustainable development, the concrete of tomorrow should not be restricted to strength and durability. Along these lines, geopolymer concrete is gaining popularity in the construction industry and considered an appropriate alternative building material which has been used in different field applications like precast squares, asphalt, blocks, and water tanks (Sabna et al., 2014). Geopolymers have remarkable properties like low consumption of raw resources, little $\mathrm{CO}_{2}$ emission, low production cost, less energy consumption and rapid setting.
In general, geopolymer concrete has technical advantages over traditional concrete like earlier gaining strength, higher chemical resistance, low heat of hydration, excellent resistance to sulfate attack, and good acid resistance. These features make geopolymer concrete a viable alternative in construction industries (Ngarm et al., 2015). Geopolymer concrete is formed by the reaction of the raw materials that having aluminosilicate with an alkaline solution. Therefore, several materials such as slag, fly Ash, microsilica can be used to produce geopolymer (Chindaprasirt et al., 2011). Blast furnace slag is the byproduct produced from steel industry, in the blast furnace when iron ore is reduced by coke at about 1,350 to $1,550{ }^{\circ} \mathrm{C}$. (Singh et al., 2015).

Mostly, two vital stages are involved in producing of Geopolymer solid. The first stage includes disintegration of the aluminosilicate material and arrangement polymeric species, while the second stage includes the development of particles (polymeric species) to enable the cores to attain a basic size and stimulates formation of gems (Jo et al., 2015).

Fly ash (FA) by-product, as alternatively called pulverized fuel ash, is the powder mechanically or electrostatically hastened from the fumes gases of coal-fired power stations. According to ASTM C 618-05 FA could be classified based on the originating coal (ASTM C-618/05). Also, the constituents of FA vary with the composition and source of the coal. By and large, FA particles are spherical in shape with size ranging from 0.5 to $100 \mu \mathrm{m}$ (Diaz et al., 2011). FA generally comprises a large amount of silicon dioxide exhibit in two structures crystalline and amorphous. FA also contains calcium oxide, iron oxide and aluminum oxide (Koh et al., 2010).

Sindhunata et al. (2006) examined the influence of temperature and curing time on the mechanical properties of Fly ash based geopolymer concrete. As the curing temperature and time increases, the compressive strength increases. Be that as it may, the compressive strength increases with increasing temperatures from 
60 to $90{ }^{\circ} \mathrm{C}$ for a period of 24 to $72 \mathrm{~h}$ (Antoni et al., 2013). Vinodhini et al. (2015) studied the impact of curing conditions on the quality of fly ash geopolymer concrete. Two kinds of curing methods are utilized as a part of their exploration: ambient curing at $23{ }^{\circ} \mathrm{C}$ and hot curing at $60{ }^{\circ} \mathrm{C}$. The compressive strength at day 7 for hot cured samples is seven times greater than that with ambient curing. Additionally, the compressive strength at 28-day for hot curing is about twice for ambient curing (Nurruddin et al., 2018).

According to Razak et al. (2015), there is a significant interaction between alkaline activator and fly ash ratio, influencing the development of compressive strength. By increasing Sodium silicate to Sodium hydroxide ratio from 0.6 to 1.00 in Fly ash geopolymer concrete, the compressive strength increased to the maximum. Moreover, the geopolymerisation rate increased when the Sodium silicate to Sodium hydroxide ratio is increased to 1.00. This study is aimed to investigate the effectiveness of fly ash-based geopolymer concrete as an alternative material to replace the normal concrete. The effect of sodium silicate to sodium hydroxide (alkaline activator) on mechanical and microstructural properties of geopolymer concrete was studied. Moreover, the effect of nano slag addition on the performance of produced geopolymer concrete under two curing techniques (moist and autoclave) were studied and optimized.

\section{Materials}

The basic raw materials used are fly ash powder, natural Al-Ekhaider fine aggregate, tap and distilled water, super plasticizer, coarse aggregate, nano slag and alkaline activator (Sodium Silicate + Sodium Hydroxide). The chemical composition of the fly ash and nano slag is presented in Table 1, showing that they conform to the requirements of ASTM C-618 Class F specification with strength activity index of $124 \%$ at 28 days for fly ash (FA).

Table 1. Chemical composition of fly ash* and nano slag**

\begin{tabular}{|c|c|c|c|}
\hline Constituent & Fly Ash (\%) & $\begin{array}{c}\text { Nano Slag } \\
\text { (\%) }\end{array}$ & $\begin{array}{c}\text { Limits of } \\
\text { ASTM C- } \\
618 / 05\end{array}$ \\
\hline $\mathrm{CaO}$ & --- & 1.16 & \\
\hline $\mathrm{SiO}_{2}$ & 49.582 & 67.95 & \\
\hline $\mathrm{Al}_{2} \mathrm{O}_{3}$ & 45.853 & 20.75 & $\geq 70 \%$ \\
\hline $\mathrm{Fe}_{2} \mathrm{O}_{3}$ & 4.531 & 3.50 & \\
\hline $\mathrm{SO}_{3}$ & 0.033 & 0.01 & $\leq 5$ \\
\hline $\mathrm{NaOH}+\mathrm{KOH}$ & --- & 0.50 & \\
\hline Loss on Ignition & --- & $\begin{array}{l}-- \\
\end{array}$ & $\leq 6 \%$ \\
\hline Fineness & $18 \%$ & $=63 \mathrm{~nm}^{* *}$ & $\begin{array}{c}\leq 34 \% \text { Sieve } \\
\text { No.325 }\end{array}$ \\
\hline
\end{tabular}

*Chemical tests were made by the National Center for Geological Survey and Mines

**The average particle size according to manufacture using AFM test

Sodium silicate $\left(\mathrm{Na}_{2} \mathrm{SiO}_{3}\right)$ manufactured in the United Arab Emirates was used to prepare the alkaline solution. The concentration of the $\mathrm{Na}_{2} \mathrm{SiO}_{3}$ depends on the ratio of $\mathrm{Na}_{2} \mathrm{O}$ to $\mathrm{SiO}_{2}$ anticipated. Table 2 illustrates the properties of the $\mathrm{Na}_{2} \mathrm{SiO}_{3}$ used. Commercial sodium hydroxide ( $\mathrm{NaOH})$ (Table 3), with $99 \%$ purity in flake form was used. The solids must be dissolved in distilled water to formulate an activator with the required molar concentration (10 M). Different ratios of $\mathrm{Na}_{2} \mathrm{SiO}_{3} / \mathrm{NaOH}$ were produced in to study the effect of alkaline activator on the geopolymer concrete. More water was added ( $10 \%$ by weight of FA) to increase the homogeneity of the resulting geopolymer.

Table 2. Properties of sodium silicate*

\begin{tabular}{cc}
\hline Description & Value \\
\hline Ratio of $\mathrm{SiO}_{2}$ to $\mathrm{Na}_{2} \mathrm{O}$ & $2.4 \pm 0.05$ \\
\hline $\mathrm{Na}_{2} \mathrm{O}$ percent by weight & $13.10-13.70$ \\
\hline $\mathrm{SiO}_{2}$ percent by weight & $32.00-33.00$ \\
\hline Density $-20^{\circ} \mathrm{C}$ & $51 \pm 0.5$ \\
\hline Specific Gravity & $1.534-1.551$ \\
\hline Viscosity (CPS) $20^{\circ} \mathrm{C}$ & $600-1200$ \\
\hline Appearance & Hazy
\end{tabular}

*Results according to the manufacturer

Table 3. Properties Sodium hydroxide*

\begin{tabular}{|c|c|c|c|}
\hline Appearance & $\begin{array}{c}\text { unit } \\
\text { measuring }\end{array}$ & $\begin{array}{c}\text { specification } \\
\text { ASTM E291- } \\
09\end{array}$ & Results \\
\hline $\begin{array}{c}\text { Sodium } \\
\text { hydroxide } \\
(\mathrm{NaOH}) \\
\end{array}$ & Percent & $\geq 97.5$ & 99.1 \\
\hline $\begin{array}{c}\text { Sodium } \\
\text { carbonate } \\
\left(\mathrm{Na}_{2} \mathrm{CO}_{3}\right) \\
\end{array}$ & Percent & $\leq 0.40$ & 0.22 \\
\hline $\begin{array}{l}\text { Sodium } \\
\text { chloride } \\
(\mathrm{NaCl})\end{array}$ & Percent & $\leq 0.15$ & 0.06 \\
\hline $\begin{array}{l}\text { Iron oxides } \\
\left(\mathrm{Fe}_{2} \mathrm{O}_{3}\right)\end{array}$ & Percent & $\leq 0.01$ & 0.004 \\
\hline $\begin{array}{c}\text { Sulphate as } \\
\mathrm{Na}_{2} \mathrm{SO}_{4}\end{array}$ & Ppm & $\leq 200$ & 80 \\
\hline $\begin{array}{c}\text { Copper as } \\
\mathrm{Cu}^{+2}\end{array}$ & Ppm & $\leq 4.0$ & 0.1 \\
\hline $\begin{array}{c}\text { Nickel as } \\
\mathrm{Ni}^{+2}\end{array}$ & Ppm & $\leq 5.0$ & 2.42 \\
\hline $\begin{array}{c}\text { Manganese } \\
\text { as Mn }\end{array}$ & Ppm & $\leq 4.0$ & 0.02 \\
\hline $\begin{array}{c}\text { Silicate as } \\
\mathrm{SiO}_{2}\end{array}$ & Ppm & $\leq 20$ & 14 \\
\hline $\begin{array}{c}\text { Water } \\
\text { Insoluble }\end{array}$ & Ppm & $\leq 200$ & 70 \\
\hline
\end{tabular}

\section{* Results according to the manufacturer}

Quartz-based sand that complies with I.Q.S No.45/84, zone 3 (Table 2) was used as the fine aggregate. Crushed gravel from Al-Nebai quarry was used as the coarse aggregate in all mixes. The results show that coarse aggregate conforms to the Iraqi Standard IQS 45/84. The grading and physical properties of coarse aggregate are shown in Table 4. Rheobuild SP1 is composed of synthetic polymers of modified Sulphonated naphthalene based high-range water reducer designed specially to impart rheoplastic qualities to concrete. This chemical aqueous solution which is commercially known as (MasterRHEOBULD SP1) imported from Sika Company in 
Egypt, was used in all mixes following the ASTM C 494/05 type $F$.

Table 4. Properties of fine aggregates*

\begin{tabular}{ccc}
\hline Sieve size $(\mathbf{m m})$ & $\begin{array}{c}\text { Cumulative } \\
\text { passing (\%) }\end{array}$ & $\begin{array}{c}\text { Limits of I.Q.S } \\
\text { No.45/84 }\end{array}$ \\
\hline 4.75 & 95.2 & $89-100$ \\
\hline 2.36 & 78.6 & $60-100$ \\
\hline 1.18 & 52.0 & $30-100$ \\
\hline 0.60 & 24.3 & $15-100$ \\
\hline 0.30 & 10.9 & $5-70$ \\
\hline 0.15 & 3.8 & $0-15$ \\
\hline $\mathrm{SO}_{3}$ content $=0.16 \%<0.5 \%$ limits of I.Q.S No.45/84
\end{tabular}

* Tests were made by the Concrete Laboratory in Karbala Technical Institute

\section{Experimental Procedure}

The mix proportions used in this work are shown in Table 6 as previously proposed by Al-Shathr et al. (Al-Shathr et al., 2016). Three concrete samples were chosen for each test carried out for $28 \mathrm{~d}$ to investigate compressive strength, density and splitting tensile Table 6. Mix proportions strength. Compressive strength and density tests were done using $100 \mathrm{~mm}$ cubes according to BS 1881: Part 116: 1983 and BS 1881: Part 114: 1983 standards. Meanwhile, splitting tensile strength tests were done using (100*200) mm cylindrical specimens according to BS 1881: Part 117: 1983 standards. After casting the specimens, two curing techniques were used, moist curing in water until the testing day and autoclave curing for $3 \mathrm{hrs}$ following the ASTM C-151/05.

Table 5. Properties of coarse aggregates *

\begin{tabular}{ccc}
\hline Sieve size $(\mathbf{m m})$ & $\begin{array}{c}\text { Cumulative } \\
\text { passing (\%) }\end{array}$ & $\begin{array}{c}\text { Limits of I.Q.S } \\
\text { No.45/84 }\end{array}$ \\
\hline 20 & 100 & 100 \\
\hline 14 & 96 & $90-100$ \\
\hline 10 & 78 & $50-85$ \\
\hline 5 & 6 & $0-10$ \\
\hline 2.36 & --- & --- \\
\hline $\mathrm{SO}_{3}$ content $=0.07 \%<0.1 \%$ limits of I.Q.S No.45/84
\end{tabular}

* Tests were made by the Concrete Laboratory in Karbala Technical Institute

\begin{tabular}{|c|c|c|c|c|c|c|c|}
\hline Mix No. & $\begin{array}{l}\text { Fly ash } \\
\left(\mathrm{kg} / \mathrm{m}^{3}\right)\end{array}$ & $\begin{array}{c}\text { Fine aggregate } \\
\left(\mathrm{kg} / \mathrm{m}^{3}\right)\end{array}$ & $\mathrm{SP}\left(\mathrm{kg} / \mathrm{m}^{3}\right)$ & $\begin{array}{l}\text { Nano slag by } \\
\text { w.t of FA (\%) }\end{array}$ & $\begin{array}{c}\text { Coarse aggregate } \\
\left(\mathrm{kg} / \mathrm{m}^{3}\right)\end{array}$ & $\begin{array}{c}\text { Curing } \\
\text { technique }\end{array}$ & $\begin{array}{c}\mathrm{Na}_{2} \mathrm{SiO}_{3} / \mathrm{NaOH} \text { by } \\
\text { w.t of } \mathrm{FA}(\%)\end{array}$ \\
\hline $\mathrm{M} 1 / 40$ & \multirow{4}{*}{400} & \multirow{4}{*}{720} & \multirow{4}{*}{12} & 0 & \multirow{4}{*}{1100} & moist & \multirow{4}{*}{40} \\
\hline $\mathrm{M} 2 / 40$ & & & & 0 & & autoclave & \\
\hline $\mathrm{M} 3 / 40$ & & & & 0.1 & & moist & \\
\hline $\mathrm{M} 4 / 40$ & & & & 0.1 & & Autoclave & \\
\hline $\mathrm{M} 1 / 45$ & \multirow{4}{*}{400} & \multirow{4}{*}{720} & \multirow{4}{*}{12} & 0 & \multirow{4}{*}{1100} & moist & \multirow{4}{*}{45} \\
\hline $\mathrm{M} 2 / 45$ & & & & 0 & & Autoclave & \\
\hline $\mathrm{M} 3 / 45$ & & & & 0.1 & & Moist & \\
\hline M4/45 & & & & 0.1 & & Autoclave & \\
\hline $\mathrm{M} 1 / 50$ & \multirow{4}{*}{400} & \multirow{4}{*}{720} & \multirow{4}{*}{12} & 0 & \multirow{4}{*}{1100} & moist & \multirow{4}{*}{50} \\
\hline $\mathrm{M} 2 / 50$ & & & & 0 & & autoclave & \\
\hline $\mathrm{M} 3 / 50$ & & & & 0.1 & & Moist & \\
\hline M4/50 & & & & 0.1 & & Autoclave & \\
\hline
\end{tabular}

All specimens shall be moist cured at $73.5 \pm 3.5^{\circ} \mathrm{F}[23.0 \pm$ $2.0^{\circ} \mathrm{C}$ ] from the time of molding until the moment of test following the ASTM C/192-05. Meanwhile, the autoclave shall be equipped with automatic controls and a rupture disk with a bursting pressure of 350 psi $(2.4 \mathrm{MPa}) \pm 5 \%$. The automatic control shall be capable of maintaining the gage pressure at $295 \pm 10$ psi $(2 \pm 0.07 \mathrm{MPa})$ for at least $3 \mathrm{~h}$. A gage pressure of $295 \pm 10$ psi corresponds to a temperature of $420 \pm 3{ }^{\circ} \mathrm{F}\left(216 \pm 2{ }^{\circ} \mathrm{C}\right)$. In addition, geopolymer concrete samples from three different mixtures were analyzed using X-ray diffractometer (XRD) analysis to characterize their reaction products. XRD is an attractive analytical technique for geopolymer concrete research because of the speed and simplicity at which testing is conducted. Additionally, this technique is nondestructive and requires only a few grams of material for analysis, thus it is a powerful tool used in studying crystalline materials.

\section{Results and discussion}

The effect of curing techniques, the addition of nano slag and different alkaline activator dosages on geopolymer concrete mixtures were illustrated in Figures 1, 2 and 3. The results in Figures 1 revealed that all the autoclave cured specimens had higher strength than moist cured specimens. This could be attributed to the rapid dissolution rate of $\mathrm{SiO}_{2}$ and $\mathrm{Al}_{2} \mathrm{O}_{3}$ that increased the rate of geopolymerization.

The addition of nano slag to geopolymer concrete mixtures has resulted in an improvement compressive strength for all specimens after $28 \mathrm{~d}$. However, the increase in the compressive strength of autoclave cured specimens containing nano slag was more than that of moist cured specimens due to the high surface area of slag, which resulted in higher pozzolanic activity (more $\mathrm{Si}^{+}$ and $\mathrm{Al}^{+}$). Nano slag reacts with Calcium hydrates rapidly (due to very high surface area) and produces calcium silicate hydrate with cementitious properties which is beneficial for filling effect of micro pores and hence, enhancement of final strength.

Furthermore, it is clear from the results that as the percentage of alkaline activator dosage increases, the compressive strength increases for all mixes except M4 at 
an alkaline dosage of $50 \%$. The reduction in strength at high concentration could be due to high $\mathrm{Na}^{+}$ions in the framework cavities of the internal structure (Sindhunata et al., 2006). Also, it was observed that the compressive strength after $28 \mathrm{~d}$ has increased by 28 , and $36 \%$ for the cases of 45 , and $50 \%$ alkaline dose compared to M1 (control mix). However, the compressive strength of the control mix was the least among all mixes.



$(\%)$

Figure 1. The compressive strength at (a) various alkaline to FA ratios; (b) various curing techniques

The tensile strength of each batch was measured after curing for $28 \mathrm{~d}$ like in the period for compressive strength measurements. Figure 2 shows the split tensile strength of all tested mixes. The increase in the values of tensile strength for the samples subjected to autoclave curing is more significant when compared with those subjected to moist curing technique except M4 at an alkaline dosage of $50 \%$. As the alkaline activator content increased from 40 to $50 \%$, the splitting tensile strength of all mixes increased accordingly. A previous study maintains the opinion that calcium in fly ash would act as a contaminant, forming hydrate assemblages that may decrease mechanical strength and slow down the rate of reaction. High calcium fly ashes show poor reactivity with alkaline activators due to their low glass content and high calcium content, and thus the geopolymer have low strength levels.

The maximum tensile strength recorded was $3.89 \mathrm{MPa}$, which corresponds to the $\mathrm{M} 3$ of $50 \%$ alkaline under moist curing, while the minimum recorded was $1.66 \mathrm{MPa}$, which corresponds to $\mathrm{M} 1$ of $40 \%$ alkaline under moist curing. The addition of nano slag increased the tensile strength for all different alkaline contents compared to $\mathrm{M} 1$ except M4 at an alkaline dosage of $50 \%$. Generally, it was observed that the tensile strength of geopolymer mixtures is around $12-17 \%$ of compressive strength. This trend is like that reported by Embong et al. (2015). The higher the alkaline activator concentration, the higher the splitting strength is except for mix M4/50. This is mainly because the concentration of alkaline activator is directly affecting the dissolution of fly ash which affects the formation of the geopolymer framework. However, the splitting strength development resulted in this research is slightly higher than that of compressive strength. This is most probably due to the incorporation of moist curing techniques which is very favorable at higher alkaline/fly ash content. On the other hand, it seems clear that autoclave curing is not preferred at higher alkaline/fly ash content due to the rapid formation of geopolymer framework associated with higher porosity and weaker ITZ.

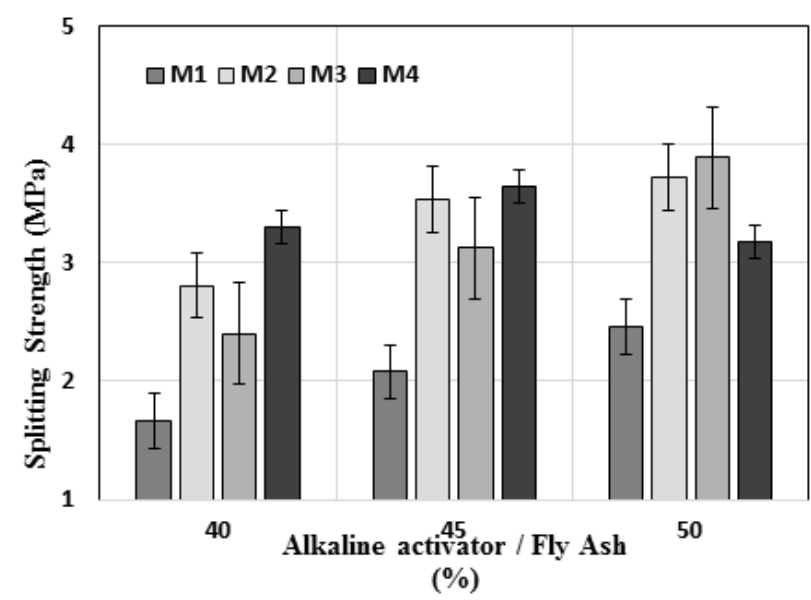

Figure 2.The splitting tensile strength at (a) various alkaline to FA ratios; (b) various curing techniques

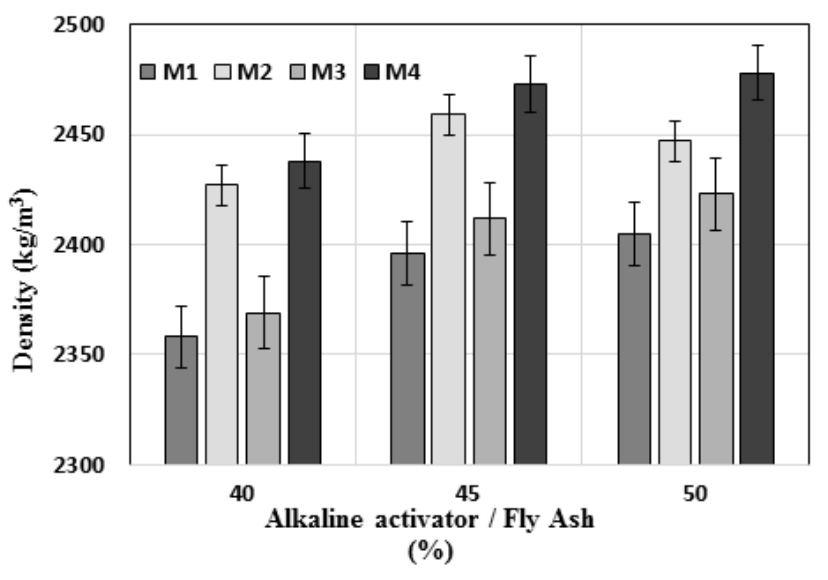

Figure 3. The density at (a) various alkaline to FA ratios; (b) various curing techniques

Figure 3 presents the relationship between density and alkaline dosage at different curing techniques (with and without nano slag). From this figure, there is a linear increase in the density of studied specimens with the increase in the alkaline dose. Moreover, a similar behavior was noticed when the curing techniques were changed from moist curing to autoclaving. Like compressive strength, the addition of nano slag to geopolymer concrete mixtures resulted in an improvement of the density for all specimens after $28 \mathrm{~d}$. This could be due to more geopolymer formation stimulated by an increase in $\mathrm{Si}^{+}$and $\mathrm{Al}^{+}$free ions.

The results presented in Figure 4 include data from three representative mixtures from the testing matrix M4 under autoclave curing technique and different amounts of alkaline (weight \% of FA). The mixtures are M4/40, M4/45, 
and $M 4 / 50$. These mixtures were chosen because they exhibit higher compressive and splitting strength than all other mixtures. According to Figure 4, Mullite (M) and Quartz (Q) amorphous humps were observed in the diffraction pattern between $2 \theta$ values of approximately $15^{\circ}$ to $30^{\circ}$ for all the investigated mixes. This could be due to the presence of amorphous glassy materials. These humps proved the creation of an alkaline aluminosilicate hydrate gel $\mathrm{N}-\mathrm{A}-\mathrm{S}-\mathrm{H}$ that has been described as the main reaction product of geopolymerization process in the diffraction patterns of geopolymer (Alehyen et al., 2017). The broad humps were detected at $2 \theta=24^{\circ}, 28^{\circ}$, and $42^{\circ}$, suggesting the presence of amorphous phases due to geopolymerization. The highest peak intensity was observed at $2 \theta=27^{\circ}$ for all samples due to the presence of Quartz. Increasing the percentage of $\mathrm{Na}_{2} \mathrm{SiO}_{3}$ induce higher $\mathrm{SiO}_{2}$ over $\mathrm{Al}_{2} \mathrm{O}_{3}$ and thus more Si-O-Si bonds, which are considered stronger than Si-O-Al bonds (Al-Shathr et al., 2016).

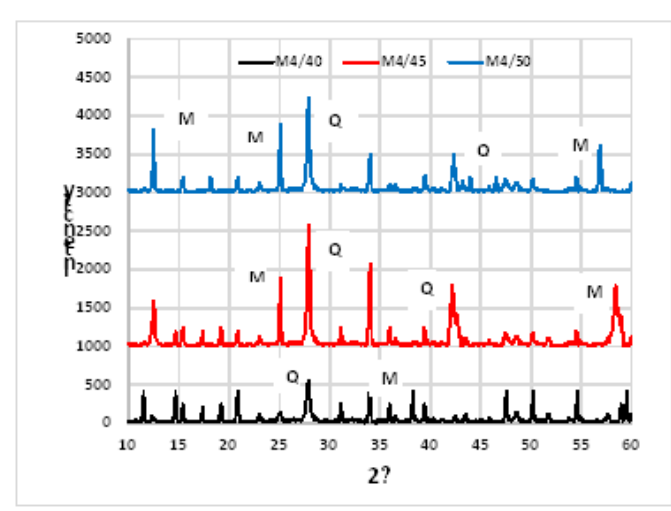

Figure 4. X-ray diffraction for mix M4 incorporated NS under autoclave curing at various alkaline to FA ratios

\section{Conclusions}

Based on the properties investigated and results obtained, observations are summarized below:

a. Higher compressive and splitting strengths were observed using autoclave curing than moist curing.

b. Addition of nano slag to the geopolymer concrete is effective towards increasing compressive and splitting strength for all mixes. However, the increase was higher under autoclave curing due to higher pozzolanic activity (more $\mathrm{Si}^{+}$and $\mathrm{Al}^{+}$).

c. The compressive and splitting strengths increase as the percentage of alkaline activator dosage increases. The observed increase in compressive strength is 28 and $36 \%$ for 45 , and $50 \%$ alkaline dosage when compared with $\mathrm{M} 1$ (the control mix).

d. The density of studied the specimens increases linearly with increase in alkaline dose.

e. Mullite (M) and Quartz (Q), the amorphous humps were observed in the diffraction pattern between $2 \theta$ values of approximately $15^{\circ}$ to $30^{\circ}$ for all the investigated mixes.

f. XRD patterns proved the existence of an alkaline aluminosilicate hydrate gel N-A-S-H, which is the main reaction product of geopolymerization process.

\section{References}

Alehyen S., EL Achouri M. and Taibi M. (2017), Characterization, microstructure and properties of fly ash-based geopolymer, Journal of Materials and Environmental Sciences, 8(5), 17831796.

Al-Shathr B., Al-Attar T. and Hasan Z. (2016), Effect of curing system on metakaolin based geopolymer concrete, Journal of Babylon University/Engineering Sciences, 24(3), 569-576.

Antoni G.R, Tjondro R., Anggono J. and Hardjit D. (2013), Effects of calcination temperature of LUSI Mud on the compressive Strength of geopolymer mortar, Advanced Materials Research, 626, 224-228.

ASTM C-618/05, Standard specification for coal fly ash and raw or calcined natural Pozzolan for use in concrete, American Society for Testing and Materials, 1-3.

Chindaprasirt P., Chareerat T., Hatanaka S. and Cao T. (2011), High-strength geopolymer using fine high-calcium fly ash, Journal of Materials in Civil Engineering (ASCE), 23(3), 264270.

Diaz L., Allouche E. and Vaidya S. (2011), Mechanical properties of fly-ash-based geopolymer concrete, ACI Materials Journal, 108(3), 300-306.

Embong R., Kusbiantoro A., Shafiq N. and Nuruddin M. (2015), Strength and microstructural properties of fly ash based geopolymer concrete containing high-calcium and waterabsorptive aggregate, Journal of Cleaner Production, 1-7.

Jo M., Soto L., Arocho M., John J. and Hwang S. (2015), Optimum mix design of fly ash geopolymer paste and its use in pervious concrete for removal of fecal coliforms and phosphorus in water, Construction and Building Materials Journal, 93, 1097-1104.

Koh K., Kang S., Ryu G., Kang H. and Lee J. (2010), Development of cementless fly ash based alkali-activated mortar, Key Engineering Materials Journal, 417-418, 721-724.

Ngarm P., Chindaprasirt P. and Sata V. (2015), Setting time, strength, and bond of high-calcium fly ash geopolymer concrete, Journal of Materials in Civil Engineering (ASCE), 27, 1-7.

Nurruddin M., Haruna S., Mohammed B. and Sháaban I.G. (2018), Methods of curing geopolymer concrete: A review, International Journal of Advanced and Applied Sciences, 5(1), 31-36.

Razak R., Al Bakri M., Hussin K., Ismail K., Hardjito D. and Yahya Z. (2015), Optimization of $\mathrm{NaOH}$ molarity, LUSI mud/alkaline activator, and $\mathrm{Na}_{2} \mathrm{SiO}_{3} / \mathrm{NaOH}$ ratio to produce lightweight aggregate-based geopolymer, International Journal of Molecular Sciences, 16, 11629-11647.

Sabna J., Sreevidya V., and Venkatasubramani R. (2014), Mechanical properties of fibrous geopolymer mortar in relation with curing conditions, International Journal of Civil and Structural Engineering, 4(3), 365-371.

Sindhunata J.S.J. van Deventer Lukey G.C. and Xu H. (2006) Effect of curing temperature and silicate concentration on fly-ash- 
based geopolymerization, Industrial \& Engineering Chemistry Research, 45(10), 3559-3568.

Singh B., Ishwarya G., Gupta M. and Bhattacharyya S.K. (2015), Geopolymer concrete: A review of some recent developments, Construction and Building Materials Journal, 85, 78-90.

Vinodhini P., Kumaravel S. and Girija P. (2015), Effect of ambient curing in geopolymer concrete, International Journal of Applied Engineering Research, 10(51), 46-48. 